\section{Nutritive Constituents of Onion Grown from Sets as Affected by Water Supply}

\author{
Attila Ombódi ${ }^{3}$ and Noémi Koczka \\ Institute of Horticulture, Faculty of Agriculture and Environmental Sciences, \\ Szent István University, Páter Károly u. 1., Gödöllö, H-2100, Hungary
}

\author{
Andrea Lugasi ${ }^{1}$ \\ National Institute for Food and Nutrition Science, Pf. 839, Budapest, H-1437, \\ Hungary
}

\begin{abstract}
Hussein Gehad Daood ${ }^{2}$ and Mária Berki
Central Food Research Institute, Herman Ottó u. 15., Budapest, H-1022, Hungary
\end{abstract}

\author{
Lajos Helyes \\ Institute of Horticulture, Faculty of Agriculture and Environmental Sciences, \\ Szent István University, Páter Károly u. 1., Gödöllö, H-2100, Hungary
}

Additional index words. air temperature, Allium cepa, irrigation, total flavonols, total polyphenols, vitamin C

\begin{abstract}
A 3-year experiment was conducted in central Hungary comparing the effect of an irrigation treatment on content and yield of dry matter, storage carbohydrates, vitamin $\mathrm{C}$, total flavonols, and total polyphenols of onion (Allium cepa $\mathrm{L}$.) grown from sets. Rain-fed plots were set as controls. Conditions during the first 40 days of the growing season had a decisive effect on yield and bulb size; warmer and dryer weather during this period resulted in lower yield. Colder and wetter weather conditions resulted in higher bulb yield, but also decreased accumulation of secondary metabolites. Dry matter content values ranged between $12 \%$ and $14 \%$ and were not influenced by the water supply. Storage carbohydrate-to-dry matter ratio was not changed by the water supply. Total flavonol contents (sum of the concentrations of nine individual flavonols) varied between 430 and $753 \mathrm{mg} \cdot \mathrm{kg}^{-1}$ on a fresh weight basis. Total polyphenol values ranged between 607 and $1029 \mathrm{mg} \cdot \mathrm{kg}^{-1}$ on a fresh weight basis. A statistically significant correlation was found between flavonol content and polyphenol content for the rainfed treatment, but this was not the case for the irrigation treatment. Irrigation significantly increased total flavonol and total polyphenol concentrations during the dry years. Irrigation significantly increased the bulb yield by $33 \%$ to $160 \%$, depending on the year. Consequently, by applying irrigation, yields of nutritive compounds became 1.5 to two times higher.
\end{abstract}

Onion can be propagated three different ways: by direct seeding, from transplants, and through sets (small dry onion bulbs raised specifically for planting) (Serra and Currah, 2002). Although sets require more investments than direct seeding, sets are easier to grow successfully and are widely used by small-scale producers (Brewster,

Received for publication 19 Sept. 2013. Accepted for publication 10 Oct. 2013.

This study was funded in part by TECH-09-A3-20090230 USOK2009, TÁMOP-4.2.1. B-11/2/KMR 2011-0003, Research Centre of Excellence-175864/2013/TUDPOL Szent István University, and KTIA_AIK_12-1-2012-0012 projects.

${ }^{1}$ Present address: Budapest Business School, College of Commerce, Catering and Tourism, Department of Catering, Alkotmány u. 9-11, Budapest, H-1054, Hungary.

${ }^{2}$ Present address: Regional Science Center, Szent István University, Páter K. u. 1., Gödöllő, H-2100, Hungary.

${ }^{3}$ To whom reprint requests should be addressed; e-mail ombodi.attila@mkk.szie.hu.
2002). Onion bulbs are especially rich in flavonoids belonging to the flavonol, dihydroflavonol, and anthocyanin subgroups (PérezGregorio et al., 2014; Slimestad et al., 2007). As a result of these compounds, onions have medicinal properties, for example antibiotic, antithrombotic, antiasthmatic, and anticancer effects (Griffith et al., 2002).

Although onions can survive long periods with a shortage of water, their photosynthetic activity and growth rate are very sensitive to water stress (Brewster, 2008). Accordingly, onions react well to irrigation under arid conditions, producing higher yields and good bulb quality with increased watering and irrigation frequency regardless of the type of irrigation system used (Enciso et al., 2009; Kumar et al., 2007; Leskovar et al., 2012; Pejic et al., 2011; Shock et al., 2000). For onions, the irrigation criterion for soil water tension varies from 8.5 to $45 \mathrm{kPa}$, depending on the environmental conditions and irrigation system (Shock and Wang, 2011). However, excessive watering can actually reduce yields in regions with adequate rainfall (Brewster, 2008), and occasionally irrigation can reduce dry matter content in onions (Pejic et al., 2011).

Water supply effects on the nutritive value of onions raised from sets have not been investigated in detail. Therefore, the objective of this study was to examine the influence of irrigation on dry matter concentration, storage carbohydrates, vitamin $\mathrm{C}$, total flavonols and polyphenols of onions raised from sets compared with a rain-fed control.

\section{Materials and Methods}

Experimental conditions and plant material. The present work was conducted in 2010 , 2011, and 2012 at the Experimental Farm of the Institute of Horticulture, Szent István University, Gödöllö, Hungary (lat. 47 $61^{\prime}$ $\mathrm{N}$, long. $19^{\circ} 32^{\prime} \mathrm{E}$ ) each year on a different field. The soil at the experimental sites was a loamy sand classified as Cambisol, having neutral $\mathrm{pH}$ (6.94 to 7.20), low salt content (electrical conductivity of 0.17 to $0.25 \mathrm{dS} \cdot \mathrm{m}^{-1}$ ), and medium organic matter content $(0.91 \%$ to $1.61 \%$ ). Air temperature and precipitation were recorded six times per hour by a Campbell CR21X meteorological instrument (Campbell Scientific Inc., Loughborough, U.K.).

Sets of a bronze-colored, long-day, Stuttgarter-type hybrid, 'Centurion' (Bejo Zaden, Warmenhuizen, The Netherlands), were planted on 20 Apr. 2010 and on 18 Apr. 2011 and 2012. The sets were obtained from a commercial supplier. Average set weight was $\approx 1.2 \mathrm{~g}$ at the time of planting. Plants were arranged in twin rows. Distance of the wider row was $50 \mathrm{~cm}$ and that of the smaller one was $25 \mathrm{~cm}$. Sets were placed at a distance of $5 \mathrm{~cm}$ in the rows, resulting in $\approx 550,000$ plants per hectare. Fertilizers were applied four times during the growth period at the summarized rate of $175 \mathrm{~kg} \cdot \mathrm{ha}^{-1}, 20 \mathrm{~kg} \cdot \mathrm{ha}^{-1}$ and $224 \mathrm{~kg} \cdot \mathrm{ha}^{-1}$ for nitrogen $(48 \%$ ammonium and $52 \%$ nitrate), phosphorus, and potassium, respectively. 
Each year, a rain-fed and an irrigated plot were established next to each other with guard rows between on a homogeneous area. The size of each plot was $81 \mathrm{~m}^{2}$ and was composed of four 27-m long twin rows. One twin row was regarded as one replication. Irrigation was performed through drip lines [Siplast mono $(20 \mathrm{~mm}$ i.d., $30 \mathrm{~cm}$ emitter spacing, $1.7 \mathrm{~L} \cdot \mathrm{h}^{-1}$ emitter discharge at $100 \mathrm{kPa}$ ); Irritec S.p.A., Capo d'Orlando, Italy] placed in the middle of the twin rows. Irrigation timing of small-scale farms was modeled. Plants were irrigated based on tensiometer (Tensiometer Classic 8060; Stelzner $\mathrm{GmbH}$, Nürnberg, Germany) readings, when the soil water tension reached $35 \mathrm{kPa}$.

Sampling areas were allocated before the harvest, one in each twin row, corresponding to four sampling areas per treatment. The exact place of a sampling area in a twin row was determined randomly. The size of a sampling area was 12 running meters of a twin row. Onions were harvested when their necks were almost completely dry, even in the irrigated treatment, on 26 Aug. 2010 and on 15 Aug. 2011 and 2012. The foliage was removed by hand when the bulbs were pulled from the soil. Immediately after soil residue removal, bulbs were counted and weighed. Yield, final plant stand per hectare, and average bulb size (g/bulb) were determined. From each replication, a 2-kg sample, with representative average bulb size, was selected for chemical analysis.

Analytical measurements. After the removal of the neck, basal plate, and skins, dry matter content was determined after freeze-drying of homogenized onion bulbs. Carbohydrate content was determined by the method of Abidin and Maier (1980). Vitamin C content was measured by a highperformance liquid chromatography (HPLC) technique based on the European Standard (2003). The analyses of total polyphenols were completed according to the FolinDenis method, spectrophotometrically at $760 \mathrm{~nm}$, using catechin as the standard (Association of Official Analytical Chemists, 1990).

For flavonol detection, $5 \mathrm{~g}$ of a wellhomogenized sample of onion flesh was extracted with a $25 \mathrm{~mL} 25: 75 \mathrm{v} / \mathrm{v}$ watermethanol containing $20 \mathrm{~mL} \cdot \mathrm{L}^{-1}$ acetic acid. After ultrasonication in a water bath for $5 \mathrm{~min}$ at room temperature and overnight storage under $5^{\circ} \mathrm{C}$, the extracts were filtered through a $0.45-\mu \mathrm{m}$ syringe polytetrafluoroethylene filter before injection to the HPLC column. A Waters Allience (Milford, MA) HPLC apparatus consisting of a Model 2695 Solvent delivery module, a Model 2996 diode-array detector, and a Model 2487 absorbance detector was used. Chromatographic separation and data processing were performed by Empower Chromatography Data software (Empower Software Solutions, Orlando, FL). The flavonols were separated on bifunctional, C18, $250 \times 4$.6-mm, Sphinx column (Mahery Nagel, Düren, Germany) with gradient elution starting with 1:99 v/v formic acid-water, changing to $40: 60 \mathrm{v} / \mathrm{v}$ acetonitrile-water in
$30 \mathrm{~min}$, which stayed isocratic for $10 \mathrm{~min}$ and then returned to $1: 99 \mathrm{v} / \mathrm{v}$ formic acid-water for $5 \mathrm{~min}$. The flavonols were identified by comparing their retention time and spectral characteristics with those of standard materials (Sigma-Aldrich, Budapest, Hungary). Quantitation was based on use of external standards and cochromatography of standard materials with the samples. Total flavonol content was calculated as a sum of the concentrations of seven identified (quercetin $7,4^{\prime}$-diglucoside, quercetin $3,4^{\prime}$-diglucoside, isorhamnetin $3,4^{\prime}$-diglucoside, quercetin $4{ }^{\prime}$-glucoside, quercetin 3- $\beta$-D-glucoside, isorhamnetin $4^{\prime}$-glucoside, quercetin) and two unidentified individual flavonol compounds.

Statistical analysis. Results were expressed as the mean of the four replications \pm SES. Effects of irrigation were analyzed by performing unpaired two-tailed Student's $t$ test (in case of homoscedasticity) or Welch's $t$ test (in case of heteroscedasticity) on the data of each year separately. Correlation and regression analyses were performed separately on irrigated and on rain-fed data using Microsoft Excel 2007 software (Microsoft Inc., Redmond, WA).

\section{Results and Discussion}

Weather and irrigation conditions. Weather conditions during set establishment and early growth (first $40 \mathrm{~d}$ ), intensive bulb enlargement (June), and swelling, fall down, and ripening (last 40 d) were investigated separately (Table 1). Weather conditions for the three growing seasons were considerably different, and, as a consequence, the number and amount of irrigation also varied. Year 2010 was by far the rainiest with almost 5 -fold more precipitation during the first $40 \mathrm{~d}$ than in the other 2 years. As a result, only four irrigations were necessary during a 3-week rainless period in July with a total amount of irrigation water of $65 \mathrm{~mm}$. Year 2011 was the driest, but also had the coolest mean temperature as a result of the relatively cold weather of the last $45 \mathrm{~d}$. Eight irrigations with a total of $105 \mathrm{~mm}$ of water were applied. The highest number of irrigations (15) and amount of $(166 \mathrm{~mm})$ water were necessary in 2012 . This was the warmest year with unusually high daily maximum air temperatures in late April to early May and late July to early August. In the present study, mean air temperature for the first $40 \mathrm{~d}$ and mean air temperature for June were best at characterizing differences of climatic conditions for the three seasons.

Quantitative characteristics. Yield was significantly increased by irrigation every year (Table 2). Irrigation resulted in the smallest yield increase $(+33 \%)$ in 2010 , the year with the highest amount of precipitation. The largest yield increase $(+160 \%)$ resulting from irrigation occurred in 2012. Final plant stand was not significantly influenced by the irrigation (Table 2). The planted sets could

Table 1. Mean air temperature, precipitation, and number of rainy days of the growing periods.

\begin{tabular}{|c|c|c|c|c|}
\hline $\mathrm{Yr}$ & Period & Temperature $\left({ }^{\circ} \mathrm{C}\right)$ & Precipitation (mm) & Number of rainy days $z$ \\
\hline \multirow[t]{4}{*}{2010} & 20 Apr. to 31 May & 14.6 & 226 & 19 \\
\hline & 1 June to 30 June & 19.2 & 128 & 10 \\
\hline & 1 July to 26 Aug. & 21.8 & 87 & 12 \\
\hline & 20 Apr. to 26 Aug. & $18.8^{y}$ & $441^{x}$ & $41^{x}$ \\
\hline \multirow[t]{4}{*}{2011} & 18 Apr. to 31 May & 15.2 & 42 & 8 \\
\hline & 1 June to 30 June & 20.1 & 61 & 7 \\
\hline & 1 July to 15 Aug. & 20.0 & 68 & 12 \\
\hline & 18 Apr. to 15 Aug. & $18.3^{y}$ & $171^{x}$ & $27^{x}$ \\
\hline \multirow[t]{4}{*}{2012} & 18 Apr. to 31 May & 15.8 & 48 & 7 \\
\hline & 1 June to 30 June & 20.5 & 88 & 8 \\
\hline & 1 July to 15 Aug. & 22.6 & 101 & 10 \\
\hline & 18 Apr. to 15 Aug. & $19.6^{\mathrm{y}}$ & $237^{x}$ & $25^{x}$ \\
\hline
\end{tabular}

${ }^{\mathrm{z}}$ Days with more than $1 \mathrm{~mm}$ of precipitation.

${ }^{\mathrm{y}}$ Mean of the whole growing season.

${ }^{\mathrm{x}}$ Total for the whole growing season.

Table 2. Effect of irrigation on quantitative characteristics of 'Centurion' onion grown from sets.

\begin{tabular}{|c|c|c|c|c|}
\hline Yr & Treatment & Yield $\left(\mathrm{t} \cdot \mathrm{ha}^{-1}\right)$ & Final plant stand (thousand/ha) & Avg bulb wt (g) \\
\hline \multirow{2}{*}{2010} & Rain-fed & $40.9 \pm 1.3^{z}$ & $586 \pm 35$ & $70 \pm 6$ \\
\hline & Irrigated & $54.6 \pm 2.4$ & $487 \pm 57$ & $114 \pm 6$ \\
\hline \multicolumn{2}{|c|}{ Level of significance $\mathrm{e}^{\mathrm{y}}$} & $* * y$ & NS & $*$ \\
\hline \multirow[t]{2}{*}{2011} & Rain-fed & $29.6 \pm 1.3$ & $470 \pm 62$ & $67 \pm 10$ \\
\hline & Irrigated & $46.6 \pm 1.7$ & $499 \pm 61$ & $99 \pm 15$ \\
\hline \multicolumn{2}{|c|}{ Level of significance } & $* * *$ & NS & NS \\
\hline \multirow[t]{2}{*}{2012} & Rain-fed & $15.6 \pm 1.4$ & $521 \pm 15$ & $30 \pm 3$ \\
\hline & Irrigated & $40.7 \pm 2.1$ & $559 \pm 53$ & $74 \pm 4$ \\
\hline \multicolumn{2}{|c|}{ Level of significance } & $* * *$ & NS & $* * *$ \\
\hline
\end{tabular}

${ }^{\mathrm{z}}$ Values are the means of four samples $( \pm \mathrm{SE})$.

${ }^{y}$ Determined by unpaired two-tailed $t$ tests within the years.

$\mathrm{NS}, *, * *, * * *$ Nonsignificant or significant at $P \leq 0.05,0.01$, or 0.001 , respectively. 
establish and produce harvestable bulbs both with and without irrigation. Hence, differences in yields were mainly caused by differences in average bulb weights. A significant positive correlation $[r=0.855$, number of observations $(\mathrm{n})=24, P \leq 0.001]$ was observed between yield and bulb size.

A strong negative correlation was observed between mean air temperature and yield in the early and the middle part of the growing season for both treatments (Table 3 ). Mean air temperature for the last $45 \mathrm{~d}$ of the growing season did not show a significant correlation with yield. The considerably strong correlation between mean air temperature and yield for the irrigated treatment can be explained by the high soil water tension $(35 \mathrm{kPa})$ selected as an irrigation criteria (Shock and Wang, 2011). Correlations between water supply and yield proved to be considerably weaker than that of temperature (Table 3). Similar to the temperature, the amount of water supply in the first $40 \mathrm{~d}$ showed the strongest correlation with the yield.

Correlation coefficient values indicate clearly that conditions of the early part of the growing season had a larger effect on the yield than conditions in the last $45 \mathrm{~d}$ (Table 3). Correlation coefficient values were smaller for the irrigated treatment than for the rain-fed treatment. This result indicates clearly that irrigation can moderate weather condition effects on yield.

Dry matter and storage carbohydrates. Measured dry matter contents were relatively high, ranging between $12 \%$ and $14 \%$ (Brewster, 2008). Irrigation had no influence on this parameter in any of the 3 years (Table 4$)$. Enciso et al. (2009) and Leskovar et al. (2012) also found that total soluble solid (TSS) content in onions was unaffected by the level of irrigation. Contrary to our result, Pejic et al. (2011) reported significantly higher TSS content for direct-seeded onions grown in the rain-fed control compared with the irrigation treatments carried out with sprinklers.

Despite the non-significant effect of irrigation, precipitation conditions affected dry matter content in our experiment. There was a significant negative correlation between the amount of supplied water and dry matter content for both treatments (Table 5). The lowest dry matter levels were recorded in the rainiest year (2010), whereas the highest values were measured in the driest year (2011) (Table 4). To the contrary, significant correlation was not found between mean air temperature and dry matter content for most of the cases (Table 5).

Because onion dry matter is mainly composed of storage carbohydrates (Brewster, 2008), a strong positive correlation was found between these two parameters for both treatments (Table 6). The slope of linear regression lines for the carbohydrate $x$ dry matter correlation was statistically similar, $0.749 \pm 0.110$ and $0.783 \pm 0.080$ for the rainfed control and the irrigation treatment, respectively. Hence, storage carbohydrateto-dry matter ratio was not influenced substantially by the irrigation.

Because irrigation significantly increased bulb yield without decreasing dry matter and storage carbohydrate contents, the yield of these constituents was significantly higher for the irrigation treatment, compared with the rain-fed control, in every year (Table 4). Dry matter yield of the irrigation treatment was higher by $35 \%, 57 \%$, and $168 \%$ compared with the rain-fed control in 2010, 2011, and 2012 , respectively. The highest values of dry matter yield were recorded for the irrigation treatments in 2010 and 2011, exceeding $6 \mathrm{t} \cdot \mathrm{ha}^{-1}$. Commercial yields are generally considered good at $\approx 5 \mathrm{t} \cdot \mathrm{ha}^{-1}$ of dry matter (Brewster, 2008).

Vitamin C, total flavonols, and total polyphenols. The tendency of secondary metabolite results was slightly different from those of dry matter and storage carbohydrate contents. Water supply significantly affected their concentration in six of nine cases (Table 4).

Measured vitamin $\mathrm{C}$ values [57 to 102 $\mathrm{mg} \cdot \mathrm{kg}^{-1}$ on a fresh weight (FW) basis] are comparable to the range reported by Bystrická et al. (2013) in their review. Irrigation did not affect vitamin $\mathrm{C}$ content in onions in 2010 and in 2011, whereas in 2012, vitamin C became significantly lower in the irrigation treatment compared with the rain-fed control (Table 4). As a result of the higher bulb yield, vitamin $C$ yield of the irrigation treatments became 1.5 to two times higher compared with their rain-fed counterparts (Table 4). The lowest vitamin $\mathrm{C}$ contents were measured in 2010, whereas the highest result was recorded for the rain-fed control in 2012. This tendency is the exact opposite of the one observed for bulb yield. The heat and drought stresses that caused low bulb weight in 2012 also resulted in higher vitamin $\mathrm{C}$ concentration. Meanwhile, less stressful conditions in

Table 3. Correlation between mean air temperature or water supply and bulb yield of 'Centurion' onion based on the data of 3 years $(2010-12)$.

\begin{tabular}{|c|c|c|c|c|c|}
\hline & \multirow[b]{2}{*}{ Period } & \multicolumn{4}{|c|}{ Yield (t.ha-1) } \\
\hline & & \multicolumn{2}{|c|}{ Rain-fed } & \multicolumn{2}{|c|}{ Irrigated } \\
\hline & Planting-31 May & -0.975 & $* * * z$ & -0.834 & $* * *$ \\
\hline \multirow{2}{*}{ Mean air temperature $\left({ }^{\circ} \mathrm{C}\right)$} & June & -0.937 & $* * *$ & -0.836 & $* * *$ \\
\hline & 1 July-harvest & -0.351 & NS & -0.181 & NS \\
\hline \multirow[t]{3}{*}{ Water supply $(\mathrm{mm})^{\mathrm{y}}$} & Planting_-31 May & 0.797 & ** & 0.443 & * \\
\hline & June & 0.528 & NS & -0.097 & NS \\
\hline & 1 July-harvest & 0.503 & NS & 0.055 & NS \\
\hline
\end{tabular}

${ }_{\mathrm{NS}}, *, * *, * * *$ Nonsignificant or significant at $P \leq 0.05,0.01$, or 0.001 , respectively $(\mathrm{n}=12)$.

yPrecipitation for the rain-fed treatment; precipitation plus irrigation water for the irrigated treatment.

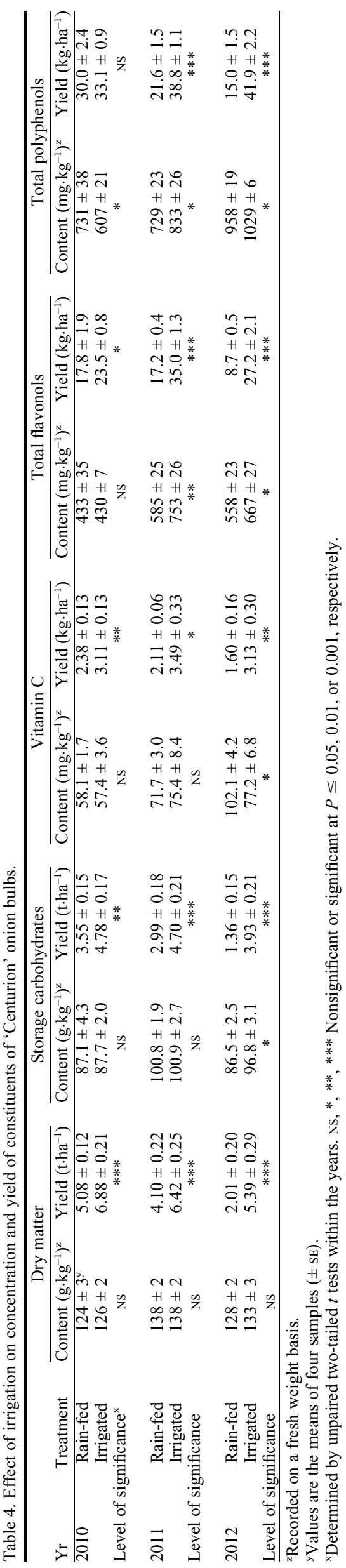

1545 


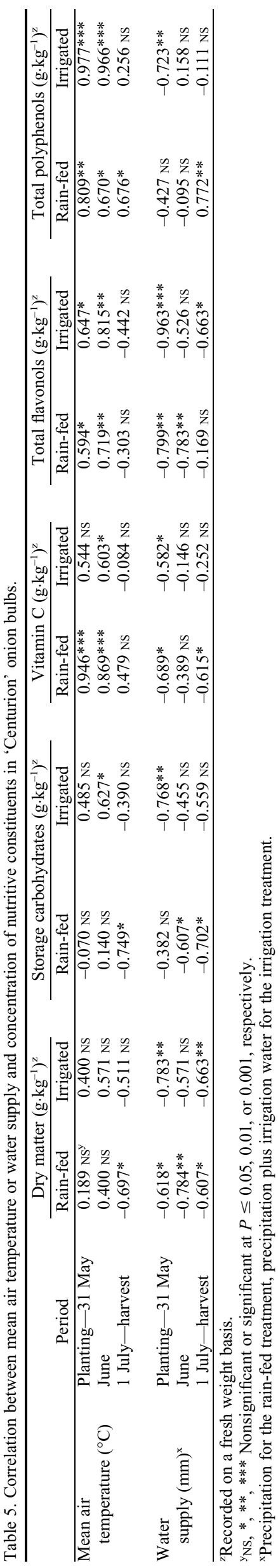

Table 6. Correlation matrix for nutritive constituents of 'Centurion' onion.

\begin{tabular}{|c|c|c|c|c|}
\hline & Storage carbohydrates & Vitamin $\mathrm{C}$ & Total flavonols & Total polyphenols \\
\hline & \multicolumn{4}{|c|}{ Rain-fed treatment } \\
\hline Dry matter & $0.906^{* * * z}$ & $0.116 \mathrm{NS}$ & $0.529 \mathrm{NS}$ & $0.217 \mathrm{NS}$ \\
\hline Storage carbohydrates & & $-0.130 \mathrm{NS}$ & $0.334 \mathrm{NS}$ & $-0.439 \mathrm{NS}$ \\
\hline Vitamin C & & & $0.516 \mathrm{NS}$ & $0.810 * *$ \\
\hline \multirow[t]{2}{*}{ Total flavonols } & & & & $0.332 \mathrm{NS}$ \\
\hline & \multicolumn{4}{|c|}{ Irrigated treatment } \\
\hline Dry matter & $0.951 * * *$ & $0.459 \mathrm{NS}$ & $0.733 * *$ & $0.452 \mathrm{NS}$ \\
\hline Storage carbohydrates & & $0.396 \mathrm{NS}$ & $0.741 * *$ & $0.513 \mathrm{NS}$ \\
\hline Vitamin C & & & $0.403 \mathrm{NS}$ & $0.642 *$ \\
\hline Total flavonols & & & & $0.692 *$ \\
\hline
\end{tabular}

2010 induced lower vitamin $\mathrm{C}$ accumulation (Table 4). Based on their 4-year onion study, Franczuk et al. (2009) have also recorded the lowest vitamin $\mathrm{C}$ content for the year with the most favorable weather conditions.

For the rain-fed control, strong positive correlations were found between mean air temperature of the early periods of the growing season and vitamin $\mathrm{C}$ content, whereas for the irrigation treatment, correlation coefficient values were much lower (Table 5). On the other hand, also significant, a negative correlation was found between the amount of supplied water during the first $40 \mathrm{~d}$ of the growing season and vitamin $\mathrm{C}$ concentration in both treatments. These results are in agreement with the conclusion of Smirnoff (2011) that unfavorable conditions can induce higher vitamin $C$ accumulation, because this compound has an important role in the tolerance to abiotic stresses. This statement can also provide an explanation for the phenomena that in our experiment, significant correlations were not found between dry matter content and vitamin $\mathrm{C}$ content and between storage carbohydrate content and vitamin $\mathrm{C}$ content, whereas a significant positive correlation was detected between vitamin $\mathrm{C}$ content and total polyphenol content (Table 6). Polyphenol accumulation has also been reported to be higher under stress conditions (Treutter, 2010).

In the present study, mean total flavonol content varied between 430 and $753 \mathrm{mg} \cdot \mathrm{kg}^{-1}$ on a FW basis (Table 4). This level is comparable to previously reported results of yellow onions, ranging between 158 and $1187 \mathrm{mg} \cdot \mathrm{kg}^{-1}$ on a FW basis (Lombard et al., 2004; Mogren et al., 2006; Slimestad et al., 2007), but it is considerably lower than total flavonol content of red onions (Pérez-Gregorio et al., 2010). Mean total polyphenol content varied between 607 and $1029 \mathrm{mg} \cdot \mathrm{kg}^{-1}$ on a FW basis (Table 4). Flavonol and polyphenol yields were higher for the irrigation treatments than for the rain-fed controls (Table 4).

In 2010 , in agreement with results of previous studies, irrigation did not affect total flavonol content, and it decreased total polyphenol content (Table 4). However, contrary to previous findings, in the current experiment, levels of these parameters significantly increased with irrigation under arid conditions of 2011 and 2012 (Table 4). According to the study of Leskovar et al. (2012), flavonol content in onions was unaffected by deficit irrigation, and Mogren (2006) did not find a correlation between onion quercetin content and soil water content. He supposed that moderate water stress did not affect onion quercetin biosynthesis. Rodrigues et al. (2011) even reported lower flavonol accumulation as a result of higher soil water availability.

Mogren et al. (2006) supposed that in onions, most of the flavonoid synthesis occurred during the last weeks before lifting. Because irrigation was cut off 3 weeks before the harvest in our experiment, there was no difference in the water supply of the treatments during that period. However, in the rain-fed plots, as a result of previous drought stresses, tops had fallen early and the foliage already withered before harvest in 2011 and 2012. Because synthesis of phenolic compounds is a chloroplastic process (Parr and Bolwell, 2000), it is supposed that in years with water deficit, irrigation treatment could result in the synthesis of more flavonols in response to climatic stresses during the irrigation cutoff period. Thus, eventually total flavonol content became higher compared with the rain-fed control. This situation is comparable to the study of Mogren et al. (2006), in which early-lifted onions were found to have lower flavonol contents than late-lifted ones. The situation was different in 2010, when both treatments matured at the same time because of the plentiful precipitation.

Considerable interannual variations were observed for total flavonols and total polyphenols (Table 4). Similar to the vitamin C data, the lowest total flavonol and polyphenol levels were recorded for the rainy year of 2010. Polyphenol level was the highest in 2012 , in the warmest season. These results are in good agreement with the findings of previous studies. Rodrigues et al. (2011) found the highest onion flavonoid levels in study. Mogren et al. (2006) reported a positive correlation between global radiation and quercetin content in onion bulbs. In the current experiment, a significant positive correlation was found between total flavonol contents and mean air temperatures and between total polyphenol contents and mean air temperatures for the early periods of the growing season, opposite of the late growing season results (Table 5). Moreover, some significant negative correlation was found between the amount of supplied water and the driest and hottest year of their 5-year 
total falvonol contents, especially for the early growing season. For total polyphenols, the tendency of these correlations was less explicit.

Notable differences were found between the two treatments while investigating the correlation among nutritive constituents. A significant positive correlation was found between dry matter content and total flavonol content and between storage carbohydrate content and total flavonol content for the irrigation treatment, whereas these correlations were not significant in the rain-fed treatment (Table 6). A significant positive correlation was found between total flavonol content and total polyphenol content for the irrigation treatment, contrary to the rain-fed treatment. These differences indicate that irrigation may affect biosynthesis of flavonols in onions grown from sets.

To summarize the findings, it can be stated that irrigation was beneficial for onions grown from sets. By increasing the yield, irrigation improved the feasibility of this traditional cultivation method. Compared with seeding, onions propagated from sets have a much more vigorous early development. Hence, conditions for the first $40 \mathrm{~d}$ of the growing season had a decisive effect on yield and bulb weight; warmer and drier weather during this period resulted in lower yield. Our results provide additional evidence on the importance of irrigation in maintaining the nutritional quality of onions while increasing the yield. Irrigation did not decrease dry matter content and storage carbohydrate content in onions grown from set; neither influenced the storage carbohydrate-to-dry matter ratio. Irrigation even had a positive effect on flavonol and polyphenol accumulation during dry years. Colder and wetter weather conditions resulted in higher bulb yield, but also decreased the accumulation of secondary metabolites. Results of this experiment performed with onions grown from sets suggest that environmental conditions of early and middle parts of the growing period have a much more important effect on the final content of secondary metabolites than those of the late season.

\section{Literature Cited}

Abidin, I. and H.G. Maier. 1980. Gleichzeitige Bestimmung von Fructose, Glucose und Saccharose mit der Anthron-Reaktion. Chemie, Mikrobiologie, Technologie der Lebensmittel. 6:121-123.

Association of Official Analytical Chemists (AOAC). 1990. Official methods of analysis. 15th Ed. Method 952.03/A-C. AOAC International, Arlington, VA.

Barnóczki, A. 2004. Vöröshagyma, p. 213-221. In: Hodossi, S., A. Kovács, and I. Terbe (eds.) Zöldségtermesztés szabadföldön. Mezőgazda Kiadó, Budapest, Hungary.

Brewster, J.L. 2008. Onions and other vegetable Alliums. 2nd Ed. CABI, Wallingford, UK.

Bystrická, J., J. Musilová, A. Vollmannová, M. Timoracká, and P. Kavalcová. 2013. Bioactive components of onion (Allium cepa L.): A review. Acta Aliment. 42:11-22.

Enciso, J., B. Wiedenfeld, J. Jifon, and S. Nelson. 2009. Onion yield and quality response to two irrigation scheduling strategies. Sci. Hort. 120:301-305.

European Standard. 2003. BS EN 14130:2003. Foodstuffs. Determination of vitamin C by HPLC.

Franczuk, J., R. Jablonska-Ceglarek, A. ZaniewiczBajkowska, E. Kosterna, and R. Rosa. 2009. The effect of plant mulches on the nutritive value of red cabbage and onion. Veg. Crops Res. Bul. 70:125-134.

Griffith, G., L. Trueman, T. Crowther, B. Tomas, and B. Smith. 2002. Onions: A global benefit to health. Phytother. Res. 16:603-615.

Keusgen, M. 2002. Health and Alliums, p. 357 378. In: Rabinovitch, H.D. and L. Currah (eds.). Allium crop science: Recent advances. CABI, Wallingford, UK.

Kumar, S., M. Imtiyaz, A. Kumar, and R. Singh. 2007. Response of onion (Allium cepa L.) to different levels of irrigation water. Agr. Water Mgt. 89:161-166.

Leskovar, D.I., S. Agehara, K. Yoo, and N. Pascual-Seva. 2012. Crop coefficient-based deficit irrigation and planting density for onion: Growth, yield, and bulb quality. HortScience 47:31-37.

Lombard, K.A., E. Geoffriau, and E.B. Peffley. 2004. Total quercetin content in onion: Survey of cultivars grown at various locations. HortTechnology 14:628-630.

Mogren, L. 2006. Quercetin content in yellow onion (Allium cepa L.): Effects of cultivation methods, curing and storage. Swedish University of Agricultural Sciences, Alnarp, Sweden.
$\mathrm{PhD}$ thesis, Acta Universitatis Agriculturae Sueciae. 2006/96.

Mogren, L.M., M.E. Olsson, and U.E. Gertsson. 2006. Quercetin content in field cured onions (Allium cepa L.): Effects of cultivar, lifting time, and nitrogen fertilizer level. J. Agr. Food Chem. 54:6185-6191.

O'Connor, D. 2006. Production of onion sets and onions from sets. Veg. Crops Res. Bul. 64:181187.

Parr, A.J. and G.P. Bolwell. 2000. Phenols in the plant and in man: The potential for possible nutritional enhancement of the diet by modifying the phenols content or profile. J. Sci. Food Agr. 80:985-1012.

Pejic, B., J. Gvozdanovic-Varga, S. Milic, A. Ignjatovic-Cupina, D. Krstic, and B. Cupina. 2011. Effect of irrigation schedules on yield and water use of onion (Allium cepa L.). Afr. J. Biotechnol. 10:2644-2652.

Pérez-Gregorio, M.R., J. Reguerio, J. Simal-Gándara, A.S. Rodrigues, and D.P.F. Almeida. 2014. Increasing the added-value of onions as a source of antioxidant flavonoids: A critical review. Crit. Rev. Food Sci. Nutr. DOI:10.1080/ 10408398.2011.624283.

Pérez-Gregorio, R.M., M.S. García-Falcó, J. SimalGándara, A.S. Rodrigues, and D.P.F. Almeida. 2010. Identification and quantification of flavonoids in traditional cultivars of red and white onions at harvest. J. Food Compost. Anal. 23:592-598.

Rodrigues, A.S., M.R. Pérez-Gregorio, M.S. GarcíaFalcón, J. Simal-Gándara, and D.P.F. Almeida. 2011. Effect of meteorological conditions on antioxidant flavonoids in Portuguese cultivars of white and red onions. Food Chem. 124:303-308.

Serra, A.D.B. and L. Currah. 2002. Agronomy of onions, p. 187-232. In: Rabinovitch, H.D. and L. Currah (eds.). Allium crop science: Recent advances. CABI, Wallingford, UK.

Shock, C.C., E.B.G. Feibert, and L.D. Saunders. 2000. Irrigation criteria for drip-irrigated onions. HortScience 35:63-66.

Shock, C.C. and F.X. Wang. 2011. Soil water tension, a powerful measurement for productivity and stewardship. HortScience 46:178-185.

Slimestad, R., T. Fossen, and I.M. Vagen. 2007. Onions: A source of unique dietary flavonoids. J. Agr. Food Chem. 55:10067-10080.

Smirnoff, N. 2011. Vitamin C: The metabolism and function of ascorbic acid in plants. Adv. Bot. Res. 59:107-177.

Treutter, D. 2010. Managing phenol contents in crop plants by phytochemical farming and breeding: Visions and constraints. Intl. J. Mol. Sci. 11:807-857. 